\title{
Chemical control of guava rust (Puccinia psidii) in the Northern Region of Rio de Janeiro State, Brazil
}

\author{
M. V. V. Martins • S. F. Silveira • L. A. Maffia • \\ J. M. A. Rocabado $\cdot$ V. Mussi-Dias
}

Received: 21 November 2008 / Accepted: 15 June 2010/Published online: 13 November 2010

(C) Australasian Plant Pathology Society Inc. 2010

\begin{abstract}
Fungicides were evaluated under field conditions for their efficacy in the control of guava rust (Puccinia psidii); five systemic fungicides (azoxystrobin, pyraclostrobin, cyproconazole, tebuconazole, triadimenol) and the protectant mancozeb. In a first trial, the fungicides were applied at two-week intervals intercalated with bi-weekly sprays of copper oxychloride. The initial incidence of rust on flower buds before treatment was $47 \%$. Triadimenol and azoxystrobin were most effective in reducing the incidence of rust on fruit. The minimum rust incidence achieved with triadimenol was $12 \%$ compared to $84 \%$ in the control treatment (water). The initial level of rust on flower buds was particularly high for the tebuconazole treatment, which may have contributed to the ineffective control by this fungicide in the first trial. In the second trial, copper oxychloride sprays were applied when disease incidence on flower buds was low (7\%). Azoxystrobin, tebuconazole, triadimenol and mancozeb treatments were started nine days after a second application of copper oxychloride. The fungicides were then applied at bi-weekly intervals and at the same concentrations as in the first trial. Triadimenol was
\end{abstract}

M. V. V. Martins ( $\bowtie)$

Embrapa Agroindústria Tropical,

Rua Dra. Sara Mesquita, 2270, Planalto Pici,

Cep: 60511-110 Fortaleza, CE, Brazil

e-mail: valentim@cnpat.embrapa.br

S. F. Silveira $\cdot$ J. M. A. Rocabado $\cdot$ V. Mussi-Dias

Laboratório de Entomologia e Fitopatologia, Universidade

Estadual do Norte Fluminense Darcy Ribeiro-UENF,

Av. Alberto Lamego 2000, Parque Califórnia,

Cep: 28015-620 Campos dos Goytacazes, RJ, Brazil

L. A. Maffia

Departamento de Fitopatologia/Universidade Federal

de Viçosa-UFV,

Viçosa, MG, Brazil again most effective in controlling rust, although its effect did not greatly differ from that of tebuconazole. The maximum disease incidence in all fungicide treatments was significantly lower than that observed in the control treatment.

Keywords Fungicides Psidium guajava . Yield losses

\section{Introduction}

Guava (Psidium guajava) is a tropical fruit with great economic potential in Brazil. In the state of Northern Rio de Janeiro, production is insufficient for the demands of the local guava industry. In 2004, the guava crop occupied a relatively small area (140 ha) in this state. The total yield was about 2335 t (SIDRA 2004) or approximately $16 \mathrm{t} \mathrm{ha}^{-1}$. Productivity is poor when compared to São Paulo State, where yields can be as high as $50 \mathrm{t} \mathrm{ha}^{-1}$ (Rocha and Bemelmans 2005). Total production can be increased by expanding the area under guava crop in Northern Rio de Janeiro, but in the absence of guava rust control, guava yields per hectare will remain low.

Guava rust is caused by Puccinia psidii Winter and the fungus was reported on other Myrtaceae, such as eucalypts (Eucalyptus spp.), jaboticaba (Myrciaria cauliflora), jambo (Syzygium jambos) and ohia (Metrosideros polymorpha) (Ferreira 1983; Alfenas et al. 1989; Coutinho et al. 1998; Alfenas et al. 2003; Uchida et al. 2006). On guava, the rust occurs on young leaves, herbaceous shoots, buds, flowers and young fruits. The disease is easily recognisable by its typical yellow spores (urediniospores) on diseased plant parts (Junqueira and Costa 2002). Infection of flowers and fruits leads to necrotic lesions, deformities, mummification and loss, which results in a reduction in fruit quantity and 
quality (Silveira et al. 1997; Rocabado 1998, 2003). When disease levels are high and no control measures are applied, there may be no harvestable fruit, especially in orchards planted with the variety Paluma, which is highly susceptible to rust (Rocabado 1998). There are no resistant commercial guava varieties to $P$. psidii (Vasconcelos et al. 1998) and control may be achieved by inducing guava trees to produce fruits during periods that are unfavorable to rust infections (Rocabado 1998, 2003) but primarily disease control has been attempted with protectant fungicides.

There are a limited number of reports about the chemical control of $P$. psidii in guava. Only a few fungicides have been evaluated under field conditions (Ferrari et al. 1997; Goes et al. 2004) mainly protectant fungicides, such as copper and mancozeb. Ferrari et al. (1997) report that application in the field of chlorothalonil, mancozeb and copper oxychloride did not significantly reduce disease levels, although chlorothalonil showed some efficacy against guava rust on fruit. Goes et al. 2004 found that copper fungicides (oxychloride, hydroxide and oxide) applied in the field were equally effective as the systemic tebuconazole in disease control. These authors also found that in the field copper fungicide or a combination of mancozeb and copper fungicide reduced rust levels on fruit, whereas mancozeb applied as a single treatment was not effective in controlling disease.

Under greenhouse conditions, systemic fungicides are more clearly effective in controlling rust in young guava plants (Ruiz et al. 1991). These authors showed the upward and lateral translocation of three systemic fungicides (triforine, triadimenol, oxycarboxin) and that triadimenol and oxycarboxin could act as protectants for up to 10 days after application. Triadimenol at $0.75 \mathrm{gL}^{-1}$ was found to have the greatest curative effect on rust disease in young guava plants (Ruiz et al. 1991). Systemic fungicides have been evaluated under greenhouse conditions for rust control in eucalypts (Ruiz et al. 1987; Ruiz and Alfenas 1989; Demuner and Alfenas 1991). Triadimenol and triforine is rapidly absorbed by the leaves of Eucalyptus grandis and suppress $P$. psidii infection in this host. Oxycarboxin, diniconazole and triadimenol when sprayed up to 28 days before pathogen inoculation protect the shoots of eucalypt seedlings.

No previous study has fully evaluated the potential of new classes of systemic fungicides for the control of guava rust in Brazil especially under the field conditions. Therefore, this study evaluates systemic strobilurins (azoxystrobin, pyraclostrobin) and triazols (cyproconazole, tebuconazole, triadimenol) for efficacy in controlling rust on Paluma guava trees planted in commercial orchards naturally infected by $P$. psidii. Systemic fungicide regimes included copper oxychloride sprays and their efficacy was compared to treatment with the non-systemic mancozeb.

\section{Methods}

Two trials were conducted in 'Paluma' guava orchards in São Francisco do Itabapoana, Northern Rio de Janeiro, Brazil. The guava trees had been planted in 1998 at a spacing of $7 \times 6 \mathrm{~m}$ and were approximately $2 \mathrm{~m}$ in height. When each trial was established, the trees were lightly pruned to encourage uniform shooting and fruiting. An experimental unit was one guava tree. The two trials were set up as randomized complete block designs with five replications.

Routine assessments of rust disease incidence were carried out during the two trials. Four branches per tree were selected at each cardinal point. Flower buds and fruits were counted starting at one metre out from the basal stem bifurcation of a branch. Disease was scored as present or absent i.e. the presence of one rust pustule meant that the flower bud or fruit was counted as being diseased. Rust incidence was calculated as the number of diseased flower buds and fruits per tree/total number of flower buds and fruits per tree, expressed in percentage. The initial assessment of rust disease was carried out 1 month after pruning.

In the first trial, undertaken from April to October 2003, six fungicides were compared: mancozeb $\left(1600 \mathrm{mgL}^{-1}\right)$; azoxystrobin, $\left(100 \mathrm{mgL}^{-1}\right)$; pyraclostrobin, $\left(100 \mathrm{mgL}^{-1}\right)$; cyproconazole, $\left(150 \mathrm{mgL}^{-1}\right)$; tebuconazole, $\left(150 \mathrm{mgL}^{-1}\right)$; and triadimenol $\left(310 \mathrm{mgL}^{-1}\right)$. Fungicide application was optimized to achieve efficient coverage with a tractormounted sprayer (6 bar pressure, $3 \mathrm{~L} /$ plant). Each of these fungicide treatments plus the control water treatment was sprayed at approximately two weekly intervals i.e. 2, 16, 30,43 and 58 days after rust disease was first assessed. During the stages of fruiting, the six fungicide treatments were alternated with a spray of copper oxychloride $\left(2400 \mathrm{mgL}^{-1}\right)$ i.e. 9,23 and 37 days after the initial rust incidence assessment. Subsequent to bud emergence, rust incidence was assessed for a period of approximately 80 days, at weekly intervals. Copper fungicide application was ceased when fruits were larger than $2 \mathrm{~cm}$ in diameter because of phytotoxicity to epidermal fruit (Goes et al. 2004). Treatment was stopped at the end of the susceptible period, when fruits reach approximately $3-4 \mathrm{~cm}$ in diameter and are immune to new infections of $P$. psidii (Rocabado 1998).

In the second trial, carried out from September 2003 to May 2004, four fungicides (azoxystrobin, tebuconazole, triadimenol and mancozeb, at the same concentrations as in the first trial) and a control water treatment were compared. The fungicides were sprayed using a back-pack sprayer with flat fan nozzles dispensing $1.5 \mathrm{~L} \mathrm{~min}^{-1}$, each plant receiving $2 \mathrm{~L}$ of fungicide suspension in each application. Copper oxychloride was sprayed twice at the start of the 
trial; 3 days after the disease was first detected and the rust incidence was $7 \%$ and again 7 days after this first application. Treatment sprays of systemic fungicides and mancozeb were applied 19, 28, 43, 57 and 72 days after the disease was first detected. After the emergence of the first buds, rust incidence was assessed over a period of 102 days, at two weekly intervals.

In the first and second trials, approximately 180 days after pruning, any fruit that was healthy and commercially acceptable was harvested at 3-day intervals. Guava yields per hectare were estimated from counts of the total number and the total weight of fruit per tree. The average production cost per hectare for a 'Paluma' guava orchard (with $7 \times 6 \mathrm{~m}$. spacing) included costs for labour, machinery, fertilizers and pesticides but not the costs of fungicides (Agrianual 2008). Fungicide prices were those current at August 2007 in the main producing areas of São Paulo state (IEA 2008). The mean value of guava fruit in 2007 in Brazil was estimated as $\mathrm{U} \$ 0.26 \mathrm{~kg}^{-1}$ (Agrianual 2008). To estimate the net income, in the second trial, the gross income per hectare was calculated from the guava fruit harvested, from which the following items were subtracted: production costs ha ${ }^{-1}$ (U\$1,296.53), fungicide costs ha $\mathrm{ha}^{-1}$ and U\$36.83 $\mathrm{ha}^{-1}$ (the cost of the two sprays of copper oxychloride).

For each treatment, including the control, disease progress curves for the rust epidemic were graphed by plotting the data for rust incidence on buds and fruits against time. Statistical analyses (ANOVA and Tukey's test $(\alpha=0.05))$ were performed using the SAEG System version 8.0 (Ribeiro Júnior 2001) to compare the following variables for each treatment: Values of Area Under the Disease Progress Curves (AUDPC) (Campbell and Madden 1990); maximum rust disease incidence (ymax); final rust disease incidence (yfinal); yield (weight and number fruit per tree).

\section{Results}

In both trials, environmental conditions favoured rust development (data not shown). In the first trial, the disease started just after the emergence of shoots. The average disease incidence on buds was already $47 \%$ when the spraying started. No fungicide effectively reduced the progression of rust disease (Fig. 1a) and the incidence levels were high on fruit (average of 14\%) at the beginning of the fruiting period. However, even with this high incidence in buds and fruits, all chemical treatments resulted in a flattening after day 21 of disease progress curves, when compared to the water treatment (Fig. 1b). There were no statistically. Despite no significant differences between most variables for each of the treatments in
Trial 1, there was a clear trend showing greater efficacy in rust control by systemic fungicides on fruit when compared to the mancozeb and water control treatments. Average ymax, yfinal and AUDPC for the water treatment were, in general, higher than those achieved with fungicide treatments. Average guava fruit yield (weight and number of fruits) was lower for the water control. The highest final disease incidence on fruits (yfinal of 48\%) (Table 1) was observed with mancozeb. The strongest negative effect on disease incidence was achieved with triadimenol (Fig. 1b), which reduced disease incidence after day 21 of treatment; the final rust incidence (yfinal) with triadimenol was significantly different to yfinal with mancozeb but not to the yfinal of other systemic fungicides. The number and the weight of fruit were extremely variable among treatments (Table 1) making it difficult to compare the efficacy of fungicides but the highest fruit yield (average no. and weight per tree) was obtained with triadimenol, the fungicide with the strongest negative effect on rust incidence.

In the second trial, the average rust incidence on buds was $7 \%$ when chemical treatment was started with two initial sprays of copper oxychloride sprays at days 3 and 10 subsequent to the initial rust assessment. The incidence of buds with rust was, at day 24 of the treatment regime, between 11 and $15 \%$ with triadimenol and tebuconazole, respectively, and $50 \%$ for the water treatment. A single application of any fungicide at 9 days after the second copper oxychloride spray slowed the progression of the disease in buds compared to the water control. This retardation of disease progress was especially marked with triadimenol and tebuconazole fungicides (Fig. 2a). Disease variables (Table 1) were significantly lower and yield variables significantly higher for all systemic fungicide treatments compared to the water control. Triadimenol and tebuconazole had similar effects in reducing rust incidence on fruit, as indicated by ymax and AUDPC. Final rust incidence (yfinal), however, for all three systemic fungicides azoxyxtrobin, triadimenol and tebuconazole treatments were comparable. The least effective rust control (in terms of yfinal) was observed with mancozeb. The number and weight of fruit per plant was significantly less with mancozeb compared to triadimenol, which resulted, as in the first trial, in the highest level of guava rust control on fruit (Figs. $1 b$ and $2 b$ ).

The yield and cost estimates associated with chemical control versus no chemical control in Trial 2 indicate that growers lose approximately U\$602/ha/season in the absence of chemical control for spray guava rust. The average yield in both trials with triadimenol was approximately $20 \mathrm{t}$ of guava fruit per hectare. Spraying with triadimenol is more expensive than the other fungicides but the potential net income is highest with triadimenol (U\$3,906.47/ha/ 
Fig. 1 Progress of rust disease on buds (a) and fruit (b) of guava 'Paluma' in a field trial undertaken in 2003 in São Francisco do Itabapoana, Rio de Janeiro State, Brazil. Arrows indicate that fungicides were sprayed at 2, 16, 30, 43 and 58 days after the first disease assessment on day 1 , and were alternated with sprays of copper oxychloride, applied at 9,23 and 37 days after day 1. Control trees were sprayed with water

Table 1 The efficacy of six fungicides against rust disease (P. psidii) in guava (P. guajava) This table shows the maximum rust incidence (ymax), final rust incidence (yfinal) on fruit, the area under the disease progress curve (AUDPC), the weight and the number of fruits per tree. The data are from two field trials in commercial orchards of $\mathrm{cv}$. 'Paluma', in São Francisco do Itabapoana, RJ, Brazil

${ }^{a}$ In each column, means with the same letter do not differ significantly (Tukey test, $\alpha=0.05$ ). Data are means \pm standard error
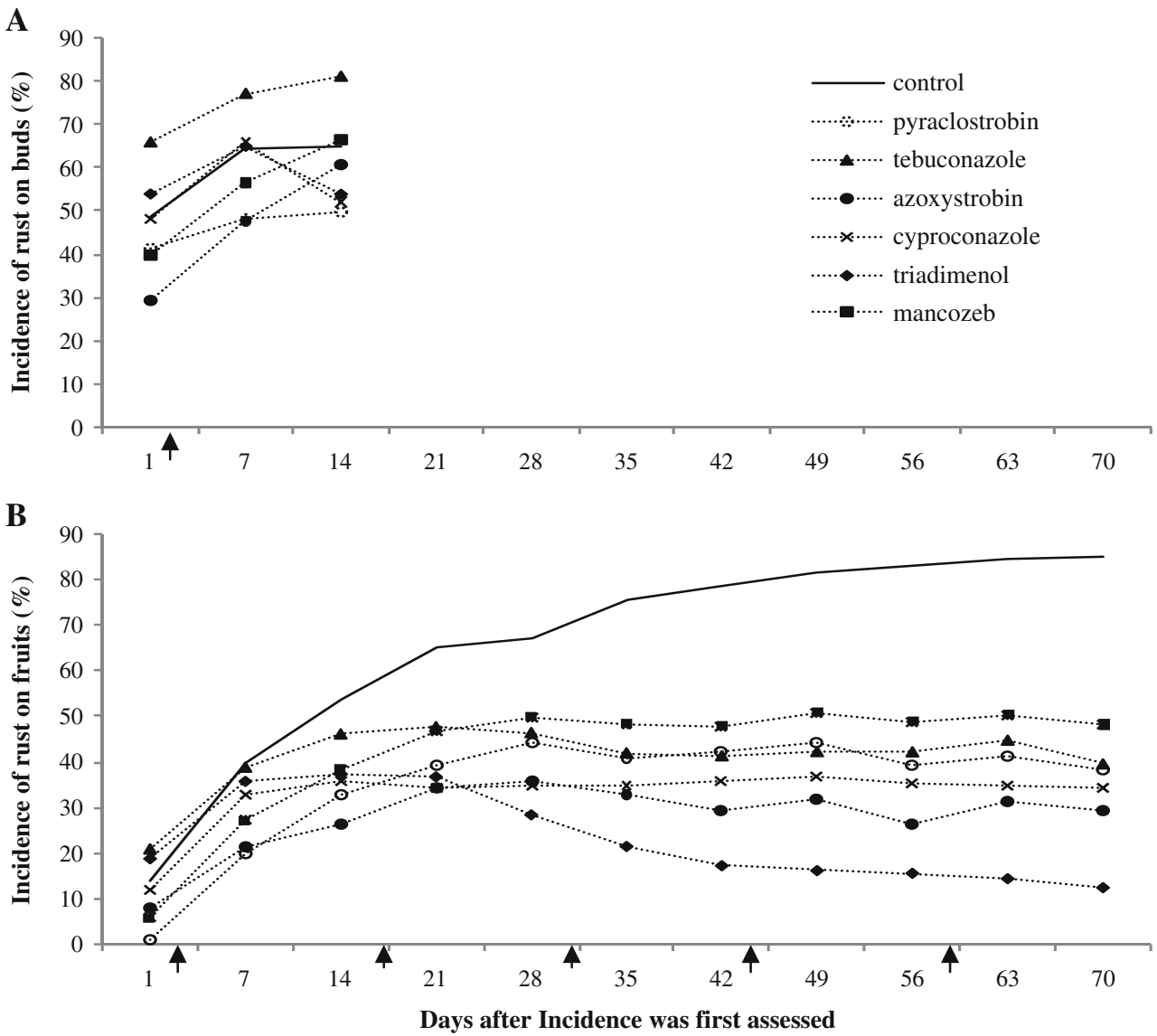

\begin{tabular}{llllll}
\hline Treatment & ymax (\%) & yfinal (\%) & AUDPC & Weight (Kg) & Number of fruits \\
\hline First trial-April to October 2003 & & & & \\
Azoxystrobin & $39 \pm 22 \mathrm{~b}^{\mathrm{a}}$ & $29 \pm 15 \mathrm{bc}$ & $2011 \pm 1199 \mathrm{~b}$ & $50 \pm 30 \mathrm{ab}$ & $311 \pm 188 \mathrm{ab}$ \\
Triadimenol & $40 \pm 24 \mathrm{~b}$ & $12 \pm 12 \mathrm{c}$ & $1672 \pm 1198 \mathrm{~b}$ & $81 \pm 19 \mathrm{a}$ & $544 \pm 106 \mathrm{a}$ \\
Cyproconazole & $42 \pm 19 \mathrm{~b}$ & $34 \pm 10 \mathrm{bc}$ & $2364 \pm 1049 \mathrm{~b}$ & $45 \pm 7 \mathrm{ab}$ & $277 \pm 39 \mathrm{ab}$ \\
Pyraclostrobin & $47 \pm 18 \mathrm{~b}$ & $38 \pm 18 \mathrm{bc}$ & $2535 \pm 1028 \mathrm{~b}$ & $40 \pm 26 \mathrm{ab}$ & $258 \pm 189 \mathrm{ab}$ \\
Mancozeb & $53 \pm 23 \mathrm{ab}$ & $48 \pm 20 \mathrm{~b}$ & $3047 \pm 1348 \mathrm{ab}$ & $38 \pm 26 \mathrm{ab}$ & $242 \pm 184 \mathrm{ab}$ \\
Tebuconazole & $55 \pm 13 \mathrm{ab}$ & $39 \pm 21 \mathrm{bc}$ & $2944 \pm 778 \mathrm{ab}$ & $35 \pm 16 \mathrm{ab}$ & $219 \pm 98 \mathrm{ab}$ \\
Control & $86 \pm 10 \mathrm{a}$ & $84 \pm 11 \mathrm{a}$ & $4735 \pm 691 \mathrm{a}$ & $10 \pm 6 \mathrm{~b}$ & $61 \pm 33 \mathrm{~b}$ \\
Mean & 52 & 40,5 & 2758 & 43 & 273 \\
CV (\%) & 33 & 38 & 36 & 52 & 52 \\
Second trial-September 2003 to May 2004 & & & \\
Triadimenol & $10 \pm 2 \mathrm{c}$ & $1 \pm 1 \mathrm{c}$ & $909 \pm 331 \mathrm{~d}$ & $87 \pm 8 \mathrm{a}$ & $560 \pm 65 \mathrm{a}$ \\
Tebuconazole & $20 \pm 5 \mathrm{c}$ & $13 \pm 4 \mathrm{c}$ & $2146 \pm 700 \mathrm{~cd}$ & $65 \pm 7 \mathrm{~b}$ & $463 \pm 37 \mathrm{ab}$ \\
Azoxystrobin & $29 \pm 12 \mathrm{bc}$ & $17 \pm 6 \mathrm{c}$ & $4803 \pm 1998 \mathrm{bc}$ & $56 \pm 13 \mathrm{~b}$ & $358 \pm 76 \mathrm{~b}$ \\
Mancozeb & $46 \pm 20 \mathrm{~b}$ & $37 \pm 19 \mathrm{~b}$ & $5739 \pm 2800 \mathrm{~b}$ & $52 \pm 6 \mathrm{~b}$ & $384 \pm 35 \mathrm{~b}$ \\
Control & $90 \pm 7 \mathrm{a}$ & $88 \pm 8 \mathrm{a}$ & $11450 \pm 1725 \mathrm{a}$ & $11 \pm 2 \mathrm{c}$ & $82 \pm 9 \mathrm{c}$ \\
Mean & 39 & 31 & 5009 & 54 & 369 \\
CV (\%) & 27 & 29 & 36 & 15 & 15 \\
\hline
\end{tabular}


Fig. 2 Progress of rust disease on buds (a) and fruit (b) of guava 'Paluma' in a field trial undertaken in 2003/2004 in São Francisco do Itabapoana, Rio de Janeiro State, Brazil. Copper oxychloride was sprayed at 3 and 10 days and fungicides at $19,28,43,57$ and 72 days (arrows) after day 1, when disease was first assessed. Control trees were sprayed with water
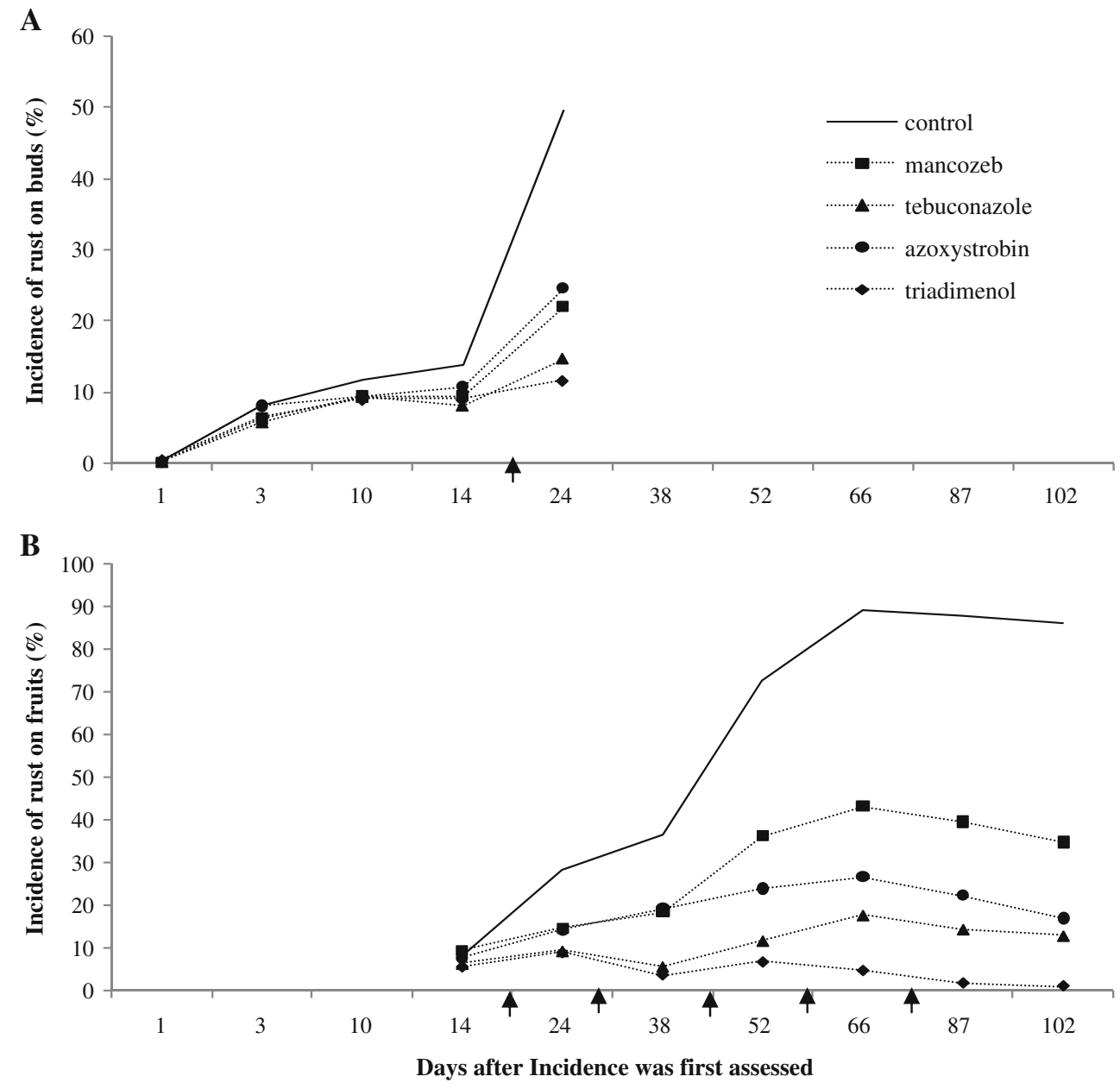

season) (Table 2) although applications of azoxystrobin, mancozeb or tebuconazole significantly increase net income (Table 2).

\section{Discussion}

Rust disease caused by $P$. psidii is the most important disease of guava in Brazil and may lead to severe losses in orchards, yet there are few reports on chemical control or assessment of systemic fungicides. We compared five systemic fungicides, mancozeb (a standard non-systemic fungicide) and water to determine the relative impact of all treatments. As indicated by previous reports (Rocabado 1998, 2003) disease progress is rapid without chemical control. Our trials demonstrated that guava production in Brazil is not economically feasible without the application of fungicides.

In the first trial, the rust disease was well established at the bud stage (incidence $=47 \%$ ) when the sprays started, and fungicide treatments were not particularly effective in buds. In the second trial, the initial rust incidence in buds

Table 2 Gross income ha ${ }^{-1}$ for guava, spray costs ha ${ }^{-1}$ for four fungicides, based on the average prices current in August 2007, and net income $\mathrm{ha}^{-1}$ from guava production in São Francisco do Itabapoana, Rio de Janeiro State, Brazil using four different fungicides in the second trial

\begin{tabular}{|c|c|c|c|}
\hline Treatment & Gross income (US\$ ha ${ }^{-1}$ ) & Cost of fungicide (US\$ ha ${ }^{-1}$ ) & Net income ${ }^{\mathrm{a}}\left(\mathrm{US} \$ \mathrm{ha}^{-1}\right)$ \\
\hline Triadimenol & $5,360.04$ & 120.21 & $+3,906.47$ \\
\hline Tebuconazole & $4,029.00$ & 56.76 & $+2,638.88$ \\
\hline Azoxystrobin & $3,481.36$ & 108.75 & $+2,039.25$ \\
\hline Mancozeb & $3,203.52$ & 33.63 & $+1,836.53$ \\
\hline Control (unsprayed) & 694.91 & - & -601.62 \\
\hline
\end{tabular}

${ }^{\mathrm{a}}$ Net income $=$ Gross income $-\left(\right.$ cost of fungicide + U\$ $36.83\left(\right.$ two sprays of copper oxychloride ha $\left.{ }^{-1}\right)+$ other production costs $($ US $\left.\$ 1,296,53)\right)$ 
was lower (7\%) and consequently, the chemical control of rust was more effective, during budding and flowering. In both trials, the disease was controlled in fruits, and the best control was achieved with systemic fungicides. Mancozeb was the least efficient of all fungicides. Despite its lower efficiency in comparison to systemic fungicides, mancozeb is preventive against guava rust under field (Ferrari et al. 1997; Goes et al. 2004) and greenhouse conditions (Ruiz et al. 1991). It should be included in a rust management program, especially to reduce the risk of $P$. psidii developing resistance to triazoles and strobilurins, as already observed with other Puccinia species (Cook 2001).

Copper fungicides, as applied in both experiments, can also be important components of a rust management program, as shown by rust control in a 'Paluma' guava orchard and in eucalyptus (Ruiz et al. 1987; Ruiz et al. 1991; Ferrari et al. 1997; Goes et al. 2004). Copper oxychloride can be used in weekly applications alternating with systemic fungicides, especially to prevent the disease at the initial stages of fruit development in guava. Copper fungicides are however phytotoxic to guava fruits of a diameter larger than $2 \mathrm{~cm}$ and cause dark spots on the epidermis (Goes et al. 2004). In both trials, no symptoms of phytotoxicity developed on the fruits, as long as copper oxychloride was sprayed only when the fruits were smaller than $2 \mathrm{~cm}$ diameter. Mancozeb or systemic fungicides, which are not associated with phytotoxic effects in guava, can be sprayed during later stages of fruit formation, when large fruits are less sensitive to copper fungicides.

Triadimenol has been clearly demonstrated to be effective against $P$. psidii in eucalyptus (Ruiz et al. 1987; Demuner and Alfenas 1991; Alfenas et al. 1993) and in young guava plants (Ruiz et al. 1991), even when treatment starts later in the disease cycle (Zauza et al. 2008). Triadimenol was similarly effective in field trials. Applied at any stage of the disease epidemic or fruit production cycle in the field (buds or fruit), triadimenol reduces inoculum levels and slows disease progress. The trend for disease incidence actually to decrease following triadimenol sprays may be explained by a reduction in fruit drop (data not shown). With triadimenol, healthy fruits remained on trees longer. Small pustules (smaller than $1 \mathrm{~mm}$ diameter) on fruit were eradicated, the incidence of diseased fruits decreased with time, fruit with healed lesions were considered as marketable and final yields with triadimenol were higher than other treatments for both trials. Azoxystrobin, cyproconazole and tebuconazole are registered in Brazil to control guava rust, but triadimenol is not. Triadimenol should be registered for the control of guava rust in Brazil as it is clearly more effective than the registered systemic fungicides especially as it eradicates small pustules.
Considering the rapid development of rust at the bud stage and afterwards, fungicide application must start at the beginning of a disease epidemic. Therefore, disease incidence at the bud stage must be regularly monitored to trigger the decision to start spraying fungicides. This requirement for the accurate timing of chemical treatment at the onset of disease was demonstrated by the second trial, in which guava trees were sprayed as soon as the first pustules appeared on buds; subsequently, the disease progress was slowed and chemical control was more effective. Preventive applications at the bud stage, with copper fungicides or systemic fungicides, may not be necessary or economically rational when rust incidence is low, especially if the weather conditions are unfavorable to the disease development, because a low incidence of rust on buds can be tolerated within the context of physiological fruit drop. An accurate rust forecasting system based on environmental triggers, with action thresholds for fungicide application is required to ensure economically viable guava production in Brazil.

Acknowledgments The authors thank the Rio de Janeiro State Research Aid Foundation (FAPERJ), which provided a scholarship for M. V. V. Martins, and the State University of North Fluminense (UENF) and the farmer Luiz Cláudio Macedo Ramos, for allowing this research to be undertaken. The authors thank Dr. Caroline Mohammed for editorial assistance.

\section{References}

Agrianual (2008) Anuário da Agricultura Brasileira. Goiaba. Instituto FNP . 335-338

Alfenas AC, Demuner NL, Barbosa MM (1989) Eucalipto: a ferrugem e as opções de controle. Correio Agrícola 1:18-20

Alfenas AC, Maffia LA, Macabeu AJ, Sartório RC (1993) Eficiência de triadimenol, oxicarboxin e diniconazole para o controle da ferrugem (Puccinia psidii) em brotações de Eucalyptus cloeziana, em condições de campo. Rev Árvore 17:247-263

Alfenas AC, Zauza EAV, Assis TF (2003) First record of Puccinia psidii on Eucalyptus globulus and E. viminalis in Brazil. Australas Plant Pathol 32:325-326

Campbell CL, Madden LV (1990) Introduction to plant disease epidemiology. Wiley-Interscience, USA, $532 \mathrm{pp}$

Cook RTA (2001) First report in England of changes in the susceptibility of Puccinia horiana, the cause of chrysanthemum white rust, to triazole and strobilurin fungicides. Plant Pathol 50:792

Coutinho TA, Wingfield MJ, Alfenas AC, Crous PW (1998) Eucalyptus rust: a disease with the potential for serious international implications. Plant Dis 82:819-925

Demuner NL, Alfenas AC (1991) Fungicidas sistêmicos para o controle da ferrugem, causada por Puccinia psidii em Eucalyptus cloeziana. Fitopatol Bras 16:174-177

Ferrari JT, Nogueira EMC, Santos AJT (1997) Control of rust (Puccinia psidii) in guava (Psidium guajava). Acta Hortic 452:55-57

Ferreira FA (1983) Ferrugem do eucalipto. Rev Árvore 7:91-109

Goes A, Martins RD, Reis RF (2004) Efeito de fungicidas cúpricos, aplicados isoladamente ou em combinação com mancozeb, na 
expressão de sintomas de fitotoxicidade e controle da ferrugem causada por Puccinia psidii em goiabeira. Rev Bras Fruticultura $26: 237-240$

IEA (2008) Defensivos Agrícolas. Extraído em: http://www.iea.sp. gov.br/out/precos/defens.php Acesso: 12/11/2008.

Junqueira NTV, Costa H (2002) Controle das doenças em goiabeira. In: Zambolim L, Vale FXR, Monteiro AJA, Costa H (eds) Controle de doenças de plantas-Fruteiras, vol 2. Suprema Gráfica e Editora Ltda, Viçosa, pp 1247-1277

Ribeiro Júnior JI (2001) Análises estatísticas no SAEG. UFV, Viçosa, $301 \mathrm{p}$

Rocabado JMA (1998) Progresso da ferrugem-da-goiabeira, causada por Puccinia psidii, em São Francisco do Itabapoana, RJ. (Tese de Mestrado). Campos. Universidade Estadual do Norte Fluminense Darcy Ribeiro

Rocabado JMA (2003) Epidemiologia e Patogênese da ferrugem-dagoiabeira, causada por Puccinia psidii. (Tese de Doutorado). Campos Universidade Estadual do Norte Fluminense Darcy Ribeiro

Rocha MB, Bemelmans PF (2005) Goiaba para indústria: o custo da matéria-prima. Extraído em: http://www.iea.sp.gov.br/out/verTexto.php?codTexto=1743. Acesso: 15/05/2005
Ruiz RAR, Alfenas AC (1989) Absorção e translocação de fungicidas sistêmicos em Eucalyptus grandis para o controle da ferrugem do eucalipto, causada por Puccinia psidii. Fitopatol Bras 14:47-50

Ruiz RAR, Alfenas AC, Ferreira FA, Zambolim L (1987) Fungicidas protetores e sistêmicos para o controle da ferrugem do eucalipto, causada por Puccinia psidii. Rev Árvore 11:56-65

Ruiz RA, Alfenas AC, Demuner NL (1991) Eficiência de fungicidas para o controle da ferrugem (Puccinia psidii) em goiabeira (Psidium guajava). Summa Phytopathol 17:147-153

SIDRA (2004) Sistema IBGE de Recuperação Automática. http:// www.sidra.ibge.gov.br/ bda/tabela/ protabl.asp? $\mathrm{z}=\mathrm{t} \& \mathrm{o}=10 \& \mathrm{i}=\mathrm{P}$ Acessed: 15/05/2005

Silveira SF, Rocabado JMA, Moreira AH, Silva EA (1997) Ferrugem e escaldadura dos ramos da goiabeira no Norte Fluminense. Fitopatol Bras S22:308

Uchida J, Zhong S, Killgore E (2006) First report of a rust disease on Ohia caused by Puccinia psiii in Hawaii. Plant Dis 90:524

Vasconcelos LFL, Alfenas AC, Maffia LA (1998) Resistência de cultivares de goiabeira à Puccinia psidii. Fitopatol Bras 23:492-494

Zauza EAV, Couto MMF, Maffia LA, Alfenas AC (2008) Eficiência de fungicidas sistêmicos no controle da ferrugem do Eucalyptus. Rev Árvore 32:829-835 